\title{
Pollen analysis of faeces as a method of demonstrating seasonal variations in the diet of Svalbard reindeer (Rangifer tarandus platyrhynchus)

\author{
Anne Elisabeth Bjune
}

\begin{abstract}
Analysis of the pollen and spore content of 40 fresh samples of faeces collected from Svalbard reindeer during 1994/5 and 1996 shows variations among and within seasons, with distinct species/pollen types dominating each season. Winter samples were characterized by high amounts of Salix and moss spores, while spring samples contained decreasing amounts of the plants grazed in winter and increasing values of species grazed in summer, such as Oxyria digyna and Pedicularis spp. Summer samples had a large quantity of pollen and a great number of pollen types. Autumn samples indicated that grasses are the most important forage species in this period. The seasonally varying proportions of pollen types are related to such factors as plant phenology, abundance, palatability and nutritional quality, as well as the preference of reindeers for grazing in low, wet areas in the summer but on higher, wind-blown ridges during the winter. The results mostly confirm other studies of Svalbard reindeer diet and grazing behaviour. The advantages and limitations of the pollen analysis method for such investigations are discussed.
\end{abstract}

A. E. Bjune, Dept. of Botany, University of Bergen, Allègaten 41, N-5007 Bergen, Norway.

Studies of the pollen content of fresh faeces from domestic sheep (Moe 1983) and goats (Justesen 1992) show variations among individual animals and among seasons in the composition of grazed species. Studies using methods other than pollen analysis of faeces (Punsvik et al. 1980; Staaland \& Punsvik 1980; Persen et al. 1983; Staaland 1984, 1986) have shown that the diet of the Svalbard reindeer varies through the year. Together with local variations in topography and snow cover, biomass and quality of plants influence the selection of food species (Persen et al. 1983). Sedentary populations, like those of the Svalbard reindeer, tend to select the most nutritious plant species in situ. In contrast, migrating species follow the developing vegetation and therefore have the opportunity of selecting plants in earlier phenological stages, when digestibility and protein levels are at their highest (Albon \& Langvatn 1992).
In summer the availability of forage plants in Svalbard is at its greatest and grazing by reindeer is more selective than in winter, when the availability of food is very limited and grazing is more restricted to areas with low snow cover. In this period, available plant biomass offers an insufficient supply of energy, proteins and minerals (Staaland 1986). In winter, the areas that are wet in the summer are no longer favoured by reindeer because of the low food quality of icecovered plants (Ekern \& Kildemo 1978). Instead, wind-blown ridges with exposed vegetation are important grazing areas for Svalbard reindeer during winter.

The purpose of this study was to demonstrate seasonal dietary variations through analysis of the pollen and spore content of faeces, and to evaluate this method for studying reindeer diet. Differences in vegetation in different parts of the study area and 


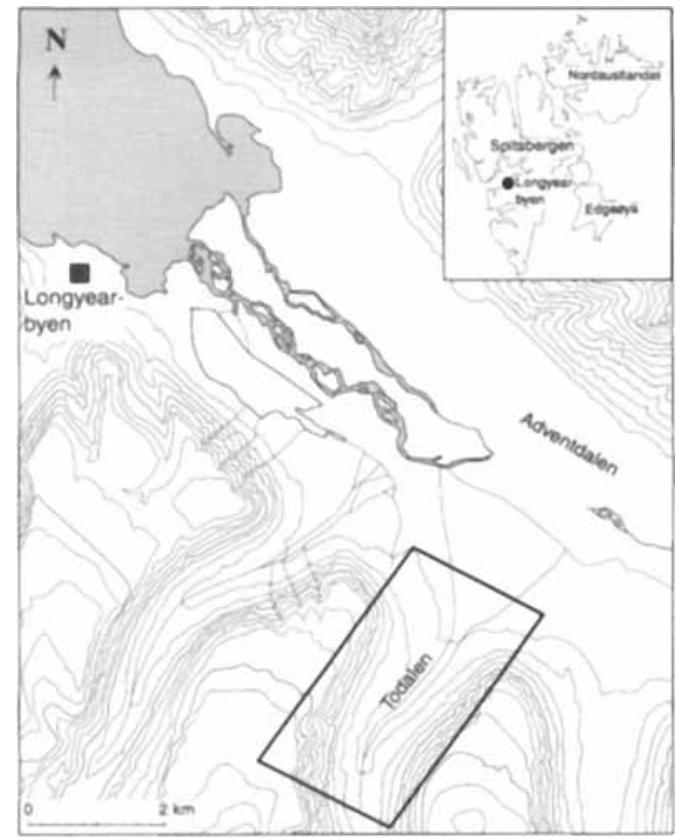

Fig. I. Maps of the study area. Contour interval is $50 \mathrm{~m}$.

factors influencing pollen production and deposition will be discussed in a forthcoming paper.

\section{The Svalbard reindeer}

The Svalbard reindeer (Rangifer tarandus platyrhynchus, Vrolik 1829) is one of seven subspecies of $R$. tarandus and is endemic to Svalbard, with a distribution between $77^{\circ} 10^{\prime} \mathrm{N}$ and $80^{\circ} 40^{\prime} \mathrm{N}$ (Tyler 1993). It is characterized by a comparatively small body, short skull, short legs and a very long, thick pelt (Krog et al. 1976). Svalbard reindeer are sedentary animals. They neither undertake long seasonal migrations nor are they nomadic within seasons like other reindeer and caribou (Tyler \& Øritsland 1989). During summer and autumn, the grazing areas have a high density of forage species, while in winter the quality and abundance of food is too low to compensate for the extra cost of moving around (Tyler \& Øritsland 1989).

\section{Study area}

The Svalbard Archipelago is situated between $74^{\circ}$ and $81^{\circ} \mathrm{N}$ and $10^{\circ}$ and $35^{\circ} \mathrm{E}$, with Spitsbergen as the main island (Fig. 1). Glaciers cover $60 \%$ of the total area and $13 \%$ is more or less covered by vegetation (Hisdal 1985). The study area was Todalen, a branch valley of Adventdalen, ca. $10 \mathrm{~km}$ south-east of Longyearbyen, western Spitsbergen (Fig. 1). The river Todalselva, flanked by low ridges going up the hillsides, bisects the valley.

The climate of Spitsbergen is Arctic. Precipitation is low $(200-400 \mathrm{~mm} / \mathrm{yr})$ and mean July temperatures range from $2.0^{\circ} \mathrm{C}$ to $6.3^{\circ} \mathrm{C}$ (Steffensen 1982). Data (1960-1990) from Svalbard Airport, near Longyearbyen, give a mean February temperature of $-16.3^{\circ} \mathrm{C}$, a mean July temperature of $5.8^{\circ} \mathrm{C}$ (Aune 1993), and $180 \mathrm{~mm} / \mathrm{yr}$ of precipitation, with August as the wettest month with $23 \mathrm{~mm}$ as mean precipitation (Førland 1993).

The vegetation is characterized by cushion, rosette and creeping plants growing in a mosaic pattern. Today, Svalbard's flora comprises 173 native vascular species (Elven \& Elvebakk 1996), 373 bryophytes (Frisvoll \& Elvebakk 1996) and 626 lichens (Elvebakk \& Hertel 1996). Todalen lies within the Cassiope tetragona zone as described by Brattbakk (1986). On dry and exposed ridges, Festuca rubra subsp. arctica, Luzula arcuata subsp. confusa, Saxifraga oppositifolia, Silene acaulis, Carex rupestris, and Polytrichum juniperinum dominate, whereas in the moderate snow beds Cassiope tetragona, Dryas octopetala and Bistorta vivipara dominate. Salix polaris occurs in most of the study area. On mesic plains and slopes, Alopecurus borealis and Equisetum arvense subsp. boreale grow together with several moss species.

The summer season is very short; snow may cover the vegetation from September until the end of May. The period when reindeer can graze fresh vegetation is therefore short (Staaland 1984). Of the 173 vascular species on Spitsbergen, Staaland (1986) assumes that only 20-30 constitute the reindeer's main diet. The other plant species are small and grow in scattered stands, representing low concentrations of biomass. In areas with a high number of species, reindeer select the species with the highest quality and biomass. Factors like palatability, nutritional quality, energy yield and digestibility are important in the selection of forage plants. Personal observations made it clear that Svalbard reindeer prefer vascular plants if available. On Spitsbergen, the biomass of lichens is low (Staaland, Brattbakk et al. 1983), and in the diet of the Svalbard reindeer digestible mosses (Staaland, Jacobsen et al. 1979; Prins 1981) replace them. 
Table 1. Dates of sample collection. and the seasons to which they were assigned on the basis of pollen quantities and types, as shown in the pollen diagram (Fig. 2).

\begin{tabular}{lcc}
\hline & Date & Samples \\
\hline Autumn & $27.08 .94-03.11 .94$ & $1-6$ \\
Winter & $23.11 .94-11.04 .95$ & $7-14$ \\
Spring & $25.04 .95-03.06 .95$ & $15-18$ \\
Summer & $15.06 .95-16.08 .95$ & $19-27$ \\
Autumn (start) & 18.09 .95 & 28 \\
Spring & $15.05 .96-21.06 .96$ & $29-34$ \\
Summer & $28.06 .96-04.08 .96$ & $35-40$ \\
\hline
\end{tabular}

\section{Materials and methods}

\section{Fieldwork}

Reindeer faeces were collected from August 1994 to August 1995 (Table 1). From August 1994 to June 1995, one sample was collected every 14 days; from June to August 1995, one sample was collected every week. In addition, a sample was collected once a week from May to August 1996.

A randomly selected reindeer, i.e. the first reindeer encountered, was followed until it produced a fresh sample of faeces, which was collected and stored in a plastic bag (Justesen 1992). The samples were frozen until preparation. In total, 40 faeces samples were collected. The faeces were collected in different vegetation types during the different seasons, depending on, among other factors, snow cover and the availability of forage plants for the reindeer. Samples were subsequently assigned to one of the four seasons (Table 1) on the basis of pollen quantities and types, as shown in the pollen diagram (Fig. 2).

\section{Laboratory work}

From each sample, 2-3 pellets were used (King 1977). They were dried at $105^{\circ} \mathrm{C}$ for 24 hours and weighed. The pellets were then dissolved in $10 \%$ $\mathrm{KOH}$ and ethanol overnight, and prepared, in accordance with Fægri \& Iversen (1989), using acetolysis and HF treatment, to remove organic and inorganic material, respectively. 1-3 Lycopodium tablets were added to each sample.

Pollen identifications were based on the keys of Fægri \& Iversen (1989) and the Ranunculaceae key of Eide (1987), together with the reference collection at the Department of Botany, University of Bergen.

Since mosses constitute a sizeable part of the reindeer diet during some parts of the year (Staaland 1984), the quantification of moss spores was important. The frequencies of moss spores can also determine the type of vegetation grazed since wet plant communities contain more mosses than dry ridges. Moss spores were subjectively identified after pictures in Boros \& Járai-Komlódi (1975). Plant nomenclature follows Fægri \& Iversen (1989) and Elven \& Elvebakk (1996). The pollen diagrams were drawn in Core version 2.0 (Kaland \& Natvik 1993).

For loss on ignition (LOI), 1-2 pellets were dried at $105^{\circ} \mathrm{C}$ for 24 hours and weighed before they were burned at $550^{\circ} \mathrm{C}$ for 6 hours and then weighed.

\section{Ordination}

Since no environmental variables were measured, and the data set has a short gradient $(L=1.95)$ indicating linear response curves, ordination by principal components analysis (PCA) was preferred (ter Braak 1987). PCA was used to differentiate between different seasons and the sample-species relationships (Table 2). Standard settings were used with square root transformation of pollen data to reduce differences between percentage values (ter Braak \& Prentice 1988). Pollen data were first transformed in TRAN version 1.7 (Juggins 1993).

Ordination was done with CANOCO version 3.12 (ter Braak 1991) and the plots made with CanoDraw version 3.0 (Šmilauer 1992).

Ordination were performed on the 1994/95 data only because this data set was the most complex one, and adding the 1996 data set does not give a more clear picture of the pollen diagram.

\section{Results}

The most marked seasonal changes, as illustrated in the pollen diagram (Fig. 2), occur within the

Table 2. Results of the PCA analysis of reindeer faeces from $1994 / 95$. Eigenvalues, $\lambda$, and cumulative percentage variance, $\mathrm{V}$.

\begin{tabular}{lll}
\hline & $\lambda$ & $\vee \%$ \\
\hline 1. axis & 0.382 & 38.2 \\
2. axis & 0.297 & 67.8 \\
3. axis & 0.143 & 82.1 \\
4. axis & 0.071 & 89.2 \\
\hline
\end{tabular}




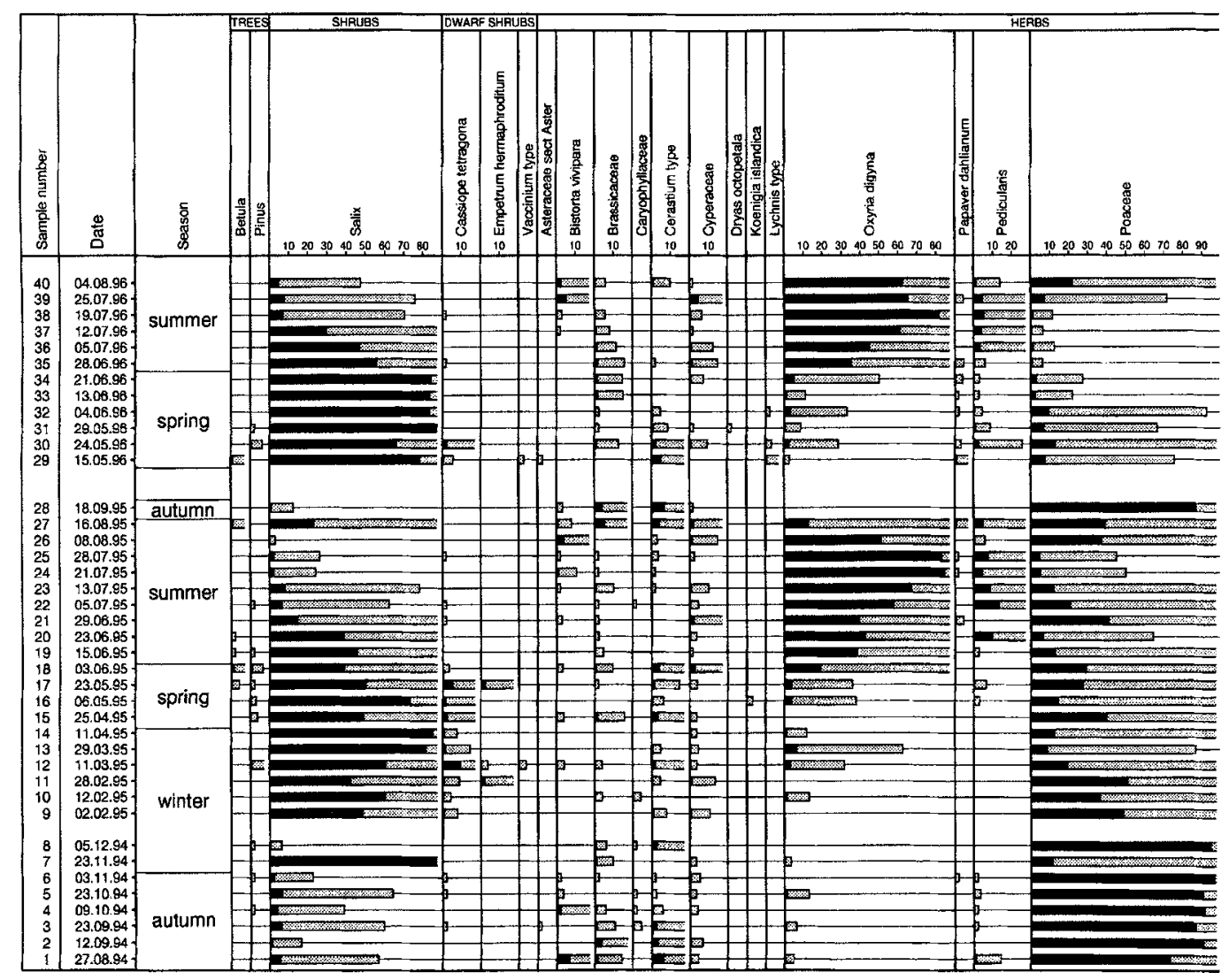

Fig. 2. Pollen diagram showing the percentages of pollen and spores in the reindeer faeces collected in the 1994/95 and the 1996 seasons, sorted by date and sample number, with the oldest sample at the bottom of the pollen diagram. Loss on ignition (LOI) is shown as the last column. Black histograms show the pollen and spore percentages, grey the $\times 10$ exaggerations. The pollen

three taxa Salix, Poaceae and Oxyria digyna, and for the purposes of this study the four seasons - the beginning and ending dates of which vary from year to year - are distinguished on the basis of the prevalence of one of these types of pollen. The PCA ordination technique shows the same division of samples from the 1994/95 series (Fig. 3a).

Collected during the autumn of 1994, samples 1-6 were dominated by Poaceae (72-98\%) (Fig. 2). More than $90 \%$ of the pollen recorded in sample 6 was Poaceae pollen, while Salix, Saxifraga oppositifolia type and Cerastium type are weakly represented. A few Caryophyllaceae and Bistorta vivipara pollen grains were found. The quantity of moss spores was small.

Winter 1994-95 samples, 7-14, were characterized by an increase in Salix and Cassiope tetragona; Salix reached maximum values in samples 13 and 14. Increasing values of moss spores, especially of Tomentypnum type, were also characteristic of the winter samples. Sample 8 differed from the other winter samples by having low values of Salix and high Poaceae values. In the other winter samples, in contrast, the quantity of grass was smaller compared to autumn samples. A few Oxyria digyna grains were recorded.

Spring 1995 samples, 15-18, contained lower values of Salix and Poaceae than the samples of the preceding season, though Salix and Poaceae still dominate these spring samples. Oxyria digyna and several Saxifraga types increase. The values of Cerastium type and Cassiope tetragona are high.

Summer 1995 samples, 19-27, showed an increase in the number of pollen types, reflecting the onset of summer and increased flowering. The $O$. digyna curve peaks in samples 24 and 25 . The number of pollen from the insect-pollinated Pedicularis spp. and the commonly viviparous 


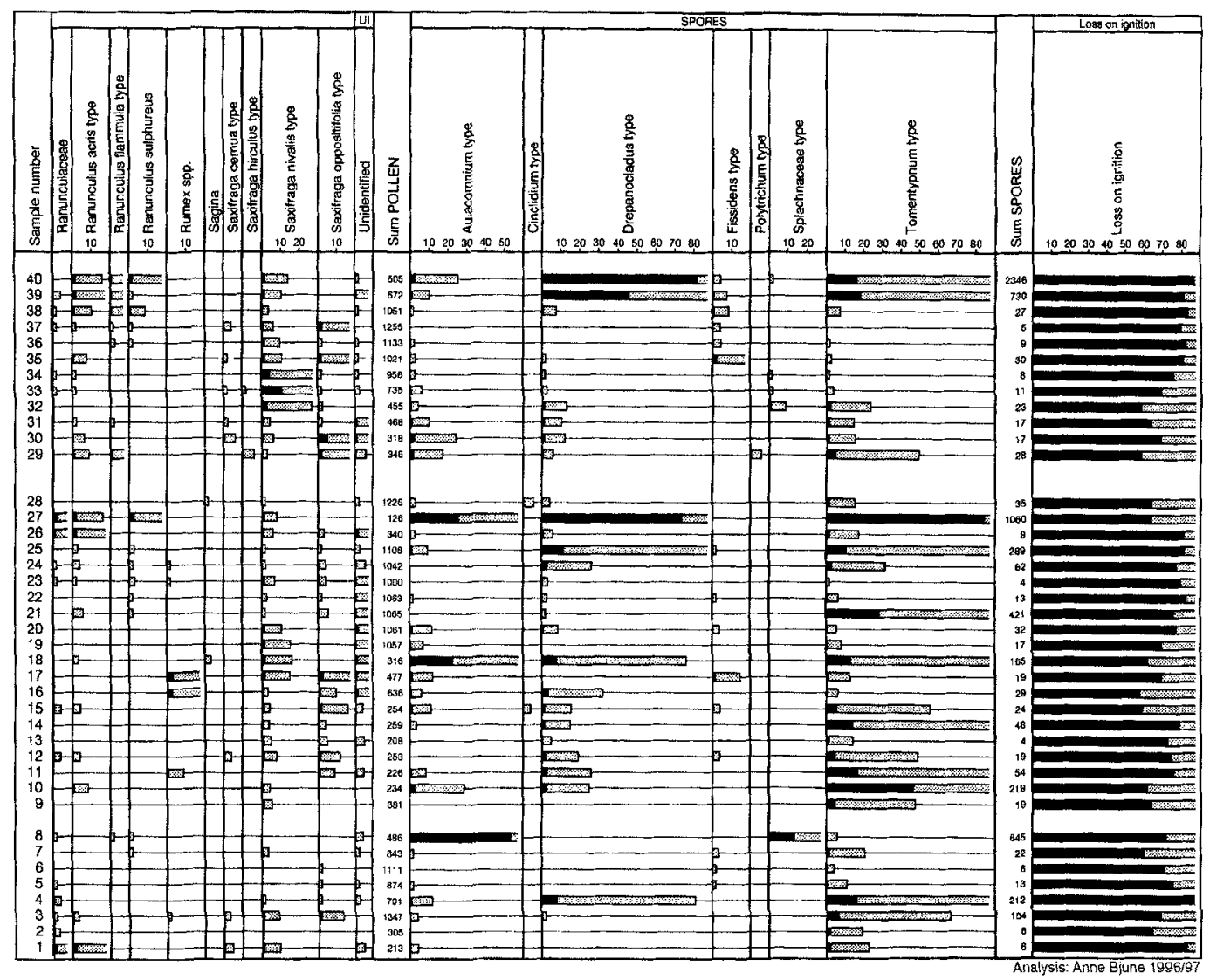

percentage values were calculated on the basis of the pollen sum ( $\Sigma P$ ) and the spore percentages according to the formula $\mathrm{X}(\Sigma \mathrm{P}+\mathrm{X})^{-1}$, where $\mathrm{X}$ is the spore type. Each spectrum was calculated alone.

Bistorta vivipara was high in these samples. On the other hand, Salix decreased through the summer. Sample 27 was unusual compared to the other summer samples in that it contained a large quantity of moss spores, particularly of Drepanocladus type and Tomentypnum type.

In the transition from summer to autumn 1995. represented by samples $26-28$, the Poaceae values increased at the expense of $O$. digyna, as occurred in the autumn of 1994.

Spring 1995 samples, 29-34, were characterized by high values of Salix, Poaceae and Saxifraga oppositifolia type, and low quantities of $O$. dignna.

Sample 35, the first of the summer 1995 samples, contained a lower amount of Salix and a markedly larger quantity of $O$. digyna compared to the preceding spring samples. In all the summer 1995 samples, 35-40, Oxyria digyna, Pedicularis spp., Ranunculus spp. and Saxifraga spp. were well-represented. The number of taxa represented in these samples was larger compared to the spring samples from the same year. In samples 39 and 40, the amount of Salix was low, the values of Oxyria digyna lower than in earlier samples, and the moss spores had comparatively high values.

From the PCA plot of the dominant species (Fig. $3 b$ ), it can be clearly seen that Salix, Saxifraga oppositifolia type and Cassiope tetragona were the most important species in the winter and spring samples, whereas Poaceae, Brassicaceae, Bistorta vivipara and Cerastium type were important in the autumn samples. The summer samples were characterized by high amounts of Oxyria digyna, Pedicularis spp., Ranunculus sulphureus and Papaver dahlianum. Eigenvalues are given in Table 2. The two first axes of the PCA plot capture almost $70 \%$ of the variance in the data set.

The few pollen grains of Betula and Pinus found 

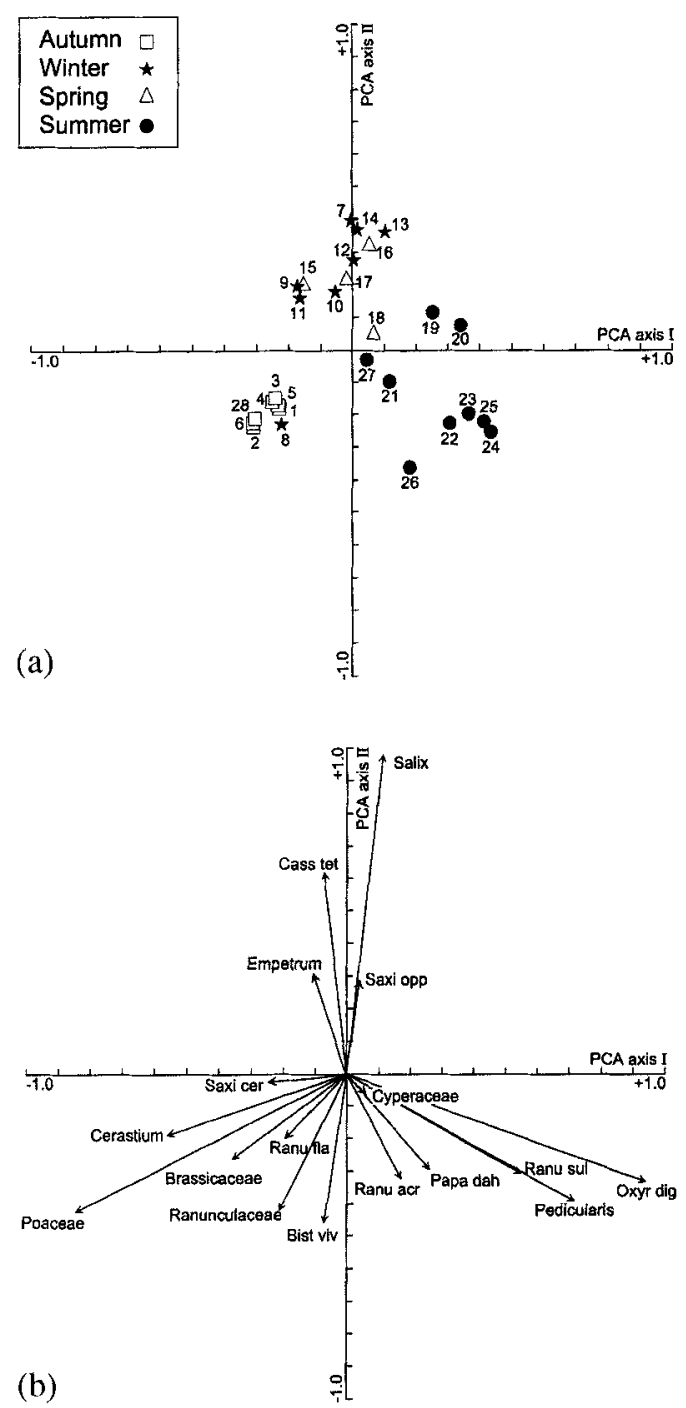

Fig. 3. (a) PCA diagram showing separation of the faeces samples from the 1994/95 series from the two first PCA axes, describing most of the variation within the data set (see Table 1). The numbers are the sample numbers (see Fig. 2). (b) PCA diagram with the pollen types explaining most of the variation in the faeces in the 1994/95 series. Abbreviations: Cass tet $=$ Cassiope tetragona; Saxi opp = Saxifraga oppostitifolia; Saxi niv $=S$. nivalis; Saxi cer $=$ S. cernua $:$ Ranu sul $=$ Ranunculus sulphureus; Ranu acr $=R$, acris $\mathrm{t}$; Ranu fla $=R$. flammula t.; Bist viv = Bistorta vivipara , Papa dah $=$ Papaver dahlianum: Oxyr dig = Oxyria digyna .

in the faeces are regarded as the result of long distance transport (Srodon 1960; van der Knaap 1987 ) and will not be discussed any further.

Loss on ignition (LOI) varied between $60 \%$ and $88 \%$ through the year. The highest values were found in the summer and autumn samples. Of all years, the sample with the highest LOI was sample 4 (autumn 1994), with 88\% organic content. The 1996 sample with the highest LOI was sample 40 (summer), with $86 \%$ organic content.

\section{Discussion}

Earlier investigations of the diet and grazing habits of Svalbard reindeer have relied on analyses of macro remains in stomach or faeces and on counting faeces (Punsvik et al. 1980; Staaland \& Punsvik 1980; Persen et al. 1983; Staaland 1984, 1986). Their results are compared to the results found in this study.

\section{Autumn}

Results from this study show that preferred forage plants in the autumn are grasses, in the pollen taxon Poaceae (Fig. 2). The biomass of grasses is high at this time of the year and grasses cover large areas in Todalen. The moist and wetter parts of the valley, dominated by taxa such as Alopecurus borealis, Deschampsia spp. and Poa spp., are important grazing areas (Punsvik et al. 1980). The intensive grazing of these areas by reindeer was observed during fieldwork.

Being wind-pollinated, grasses produce great quantities of pollen and are therefore wellrepresented in reindeer faeces. The pollen taxon Poaceae includes 33 species in Svalbard (Rønning 1996); it is difficult to determine which of these are the most important forage species solely through analysis of faeces. Studies of Svalbard reindeer grazing behaviour and plant selection (Staaland 1984) indicate that during late summer and autumn the animals feed extensively on grasses with high nutritional value, such as Dupontia spp., Alopecurus borealis and Poa spp. The importance of Poaceae in reindeer diet has also been confirmed by the botanical analysis of rumen content (Staaland, Brattbakk et al. 1983).

In this study, pollen representation of species normally found on dry and exposed ridges, such as Saxifraga oppositifolia type, was low in the autumn. The samples contained some pollen of Ranunculaceae, Bistorta vivipara, Cerastium type and Cyperaceae, providing further evidence that moist areas are the most important grazing areas during autumn. As a general rule, the moist areas include species with the highest nutritional quality 
and biomass, as well as the largest number of available forage species.

\section{Winter}

The availability of grazing in winter depends on snow and ice conditions. Punsvik \& Syvertsen (1978) have shown that in winters the PolariDryadetum communities, consisting of species such as Salix polaris, Dryas octopetala. Oxyria digyna, Bistorta vivipara and Luzula confusa growing on sparsely snow-covered ridges, are important for grazing.

This study has shown that at the transition between autumn and winter, Salix pollen values increase considerably in faeces samples; they stay high until April/May. The willows flower early in spring but their flowerbuds, containing already developed pollen, lie below the snow during winter (Strasburger et al. 1976). On the ridges, the reindeer are able to reach the Salix buds below the relatively thin layer of snow. This explains the high amount of Salix pollen content in winter faeces. The marked representation of Saxifraga oppositifolia type, Cerastium type and Cyperaceae in the winter samples provides further evidence of the importance of sparsely snow-covered ridges for grazing. (Sample 7 differs from the other winter samples by showing small values of Salix and high values of Poaceae. This may have been by chance, or due to unusually thin snow cover at a grassland locality at the sampling time.)

According to Punsvik et al. (1980), Dryas octopetala is grazed together with Festuca, Poa alpigena, $P$. arctica and Luzula confusa in winter. The stomach macro-remains of animals shot during winter in Adventdalen contained predominantly grasses, mosses and some leaves of Salix and Dryas, and less quantities of other herbs (Staaland 1986). In his study, Staaland (1986) recorded large geographical and seasonal variations. In my study, only one pollen grain of Dryas octopetala was found in the 40 samples analysed altogether (sample 31 ). So, while macro analysis shows that $D$. octopetala is an important forage species, its low pollen production results in low representation in reindeer faeces.

The winter values of Cassiope tetragona pollen were high in this study, despite Tyler's (1993) claim that Svalbard reindeer avoid C. tetragona because this species contains oils with an unpleasant taste. Several explanations for this can be suggested: 1) the $C$. tetragona pollen in this study's samples may have been deposited on the surrounding vegetation, which was then grazed by reindeer; 2) the flowers of $C$. tetragona may have been consumed unintentionally; or, most likely, 3) reindeer eat $C$. tetragona during periods of fodder shortage, even if the plant tastes bad.

As in other areas of Svalbard where there are reindeer populations, Adventdalen and its branch valleys, including Todalen, have only small amounts of lichens. Personal observations lead me to conclude that in the Adventdalen area a high grazing pressure has destroyed the lichen cover and prevents regrowth. This has resulted in a lichen biomass far too low to make lichen important as reindeer food (Staaland, Brattbakk et al. 1983). Mosses, which have high fibre and mineral content (but less nitrogen than herbs), seem to replace lichens in the diet of Svalbard reindeer (Punsvik et al. 1980; Staaland 1986). The large quantities of moss spores, especially of Tomentypnum type (Fig. 2), found in the faeces analysed in this study, support this. According to Staaland (1984), mosses are ingested in large quantities both in summer and winter. Svalbard reindeer have a better ability to digest mosses than other subspecies of reindeer (Staaland, Jacobsen et al. 1979; Prins 1981).

\section{Spring}

After the long Arctic winter, flowering on the tundra starts immediately upon snowmelt (Resvoll 1917). In spring the reindeer follow the snowmelt and graze newly exposed, fresh plants (Hjeljord 1975). According to Dubiel (1991), Saxifraga oppositifolia, Ranunculus pygmaeus and yellowflowered species of the genus Draba bloom earliest after snowmelt. The development of vegetative parts and the earliest formation of flower buds occur in some plants at a mean daily air temperature about $0^{\circ} \mathrm{C}$, and the first flowers appear when the temperature exceeds $+2.5^{\circ} \mathrm{C}$. The most intense period of flowering occurs from 10 July to 10 August (Dubiel 1991). During my fieldwork in 1995, the first flowers of Saxifraga oppositifolia were registered on 3 June.

As suggested by the pollen diagram, the exposed ridges with early snowmelt and flowering are the most important grazing areas in spring. The onset of flowering is reflected in the pollen diagram by the increase of both Saxifraga oppositifolia type and $S$. nivalis type in the spring samples. For the pollen taxon Brassicaceae, which includes the Draba species, the increase starts 
later. They are all small plants with a low biomass and are not important as forage species, and are therefore comparatively poorly represented in the faeces. Nonetheless, these early flowering species are attractive forage plants for the reindeer after a long winter with only old vegetation to graze. Salix remains an important food in spring, as shown in the pollen diagram.

Samples from the spring of 1995 and 1996 contained an increase in the amount of Oxyria digyna and Pedicularis pollen and constant values of Cerastium type, Cyperaceae and moss spores, demonstrating that fresh herbs are more attractive to reindeer than old grasses. The Poaceae values were low in the spring samples, because in spring the grasses are still of low forage quality (Staaland 1986) and are not yet in flower; new, fresh shoots of herbs are eaten in favour of the old grasses. In general, spring faeces analysed in this study showed an increase in the number of taxa, which indicates a higher flowering intensity.

\section{Summer}

Nutritious plants with good taste and high biomass are important in summertime. The faeces from both the 1995 and 1996 summer seasons were dominated by Oxyria digyna pollen, a high quality and easily digestible plant (Staaland, Brattbakk et al. 1983) which is selectively grazed (Punsvik et al. 1980; Persen et al. 1983). In addition to Oxyria digyna, high amounts of Saxifraga nivalis type, $S$. oppositifolia type, Brassicaceae, Pedicularis, Bistorta vivipara and Cyperaceae pollen in the faeces indicate grazing of these species in summer. According to van der Knaap (1989), summer faeces are characterized by high concentrations of many pollen types. Intense flowering combined with selective grazing of species in early developmental stages leads to a high number of pollen types in reindeer faeces.

Summer and autumn faeces had the highest LOI in this study. In these seasons, the organic content and biomass of the plants are high, and reindeer graze in luxuriant wet areas and meadows with little or no sand and silt. Variations within the seasons can be due to variations in the ash content of plants. Some contamination from wind-blown soil and dust may also be expected on mosses, lichens and cushion plants (Staaland, Brattbakk et al. 1983). In winter and spring, when the grazing areas are located on windblown ridges and barren areas with a discontinuous vegetation cover, the LOI in faeces was lower.

\section{Evaluation of the pollen analysis method}

The pollen analysis method for demonstrating seasonal variations in the diet of animals has both limitations and advantages. The advantages are:

- Pollen is easily recognized after digestion. In contrast, the preservation of macro remains like seeds and fruits depends on whether the animals are ruminants (Moe 1996).

- Methods for the preparation and identification of pollen are well-known and developed.

- Faeces are easy to collect and are sampled without killing, and only minimally disturbing, the animals.

However, the interpretation of pollen analysis results is not simple and straightforward. King (1977) points out that the pollen content in faeces comprises pollen from grazed plants and pollen from plants - which deposit their pollen on the surrounding vegetation - that have not been grazed. The pollen content of faeces also depends on the pollen production and phenology of individual species (Martin \& Sharrock 1964). Pollen production, dispersal and deposition vary throughout the year, with no or almost no pollen being produced during winter (Bryant 1974). In autumn in Svalbard, most species have ceased flowering and their pollen has been dispersed, either by pollination or by deposition in the adjacent vegetation or eaten by reindeer. Only a few species of grasses are still flowering at the end of August (Dubiel 1991).

Compared to plants further south, Arctic plants do not necessarily have lower pollen production per flower. But the biomass of Arctic plants is less than that of plants at more southerly latitudes, and they produce fewer flowers, leading lower total amounts of pollen. Ranunculus glacialis, for example, produces two to four flowers in alpine areas, but only one flower to each stem further north (Crawford 1989). Species like Dryas octopetala, Cerastium and Ranunculus species, which produce and release little pollen, are difficult to discover using pollen analysis.

Thus, pollen analysis of faeces as a means of 
investigating reindeer grazing patterns is limited by facts such as these:

- Pollen deposited in the vegetation from windpollinated species is difficult to separate from the wind-pollinated species of which reindeer actually consume the flowers.

- Pollen grains found in winter and autumn faeces are mainly produced during the preceding summer and deposited in the surrounding environment (Krzywinski 1976; Moe 1983). The large amounts of Salix pollen found during winter may be an exception.

- Species with predominantly vegetative reproduction, such as Saxifraga cernua and Bistorta vivipara, produce little or no pollen, so their significance as forage plants cannot be established by pollen analysis.

- Pollen and spore production and deposition of Svalbard's flora is imperfectly known.

\section{Conclusions}

The study clearly showed seasonal variation in the selection of grazing areas and species in the Svalbard reindeer. High quality species growing in the wet areas, such as Oxyria digyna, Pedicularis, Bistorta vivipara and Saxifraga oppositifolia, are grazed in summer, whereas Poaceae are important forage plants in autumn. Winter and spring faeces are characterized by pollen from Salix and different types of moss spores together with species found on the dry and exposed ridges. The results also make evident that the best periods for such studies are the spring and summer seasons, when pollen is produced.

Although the results of this study mainly confirm what is already known about the diet of Svalbard reindeer, the pollen analysis method offers a new dimension to diet studies. If samples are collected more frequently, results on a finer scale can be obtained, and variations among animals grazing on different vegetation types or in different areas can be established.

\footnotetext{
Acknowledgements. - I am grateful to Birgit Brosø, Kari Sletten and the others at UNIS in 1994-95 who assisted with my fieldwork, and also to Dagfinn Moe who has encouraged me at all stages of this work and who read the manuscript. I also wish to thank Aage Paus and Knut Fægri for valuable comments on the manuscript, and Beate $\mathrm{H}$. Ingvartsen for help with the illustrations. The Faculty of Mathematics and Natural Sciences. University of Bergen, financially supported the fieldwork.
}

\section{References}

Albon. S. D. \& Langvatn, R. 1992: Plant phenology and the benefits of migration in a temperate ungulate. Oikos 65, 502513.

Aune, B. 1993: Temperatumomaler, normalperiode 19611990. (Air temperature nomals, normal period 1961-1990.) Osio: Det Norske Meteorologiske Institutt/Universitetsforlaget.

Boros. Á. \& Járai-Komlódi, M. 1975: An atlas of recent European moss spores. Budapest: Akadémiai Kiadó.

Brattbakk, I. 1986: Vegetasjonsregioner: Svalbard og Jan Mayen. 1:1000 000. (Vegetation regions. Svalbard and Jan Maven. 1: 1000 000.) Oslo: Norwegian Polar Institute.

Bryant. V. M., Jr. 1974: Pollen analysis of prehistoric human feces from Mammoth Cave. In P. J. Watson (ed.): Archeology of the Mammoth Cave area. Pp. 203-209. New York: Cave Books.

Crawford. R. M. M. 1989: Plant survival in the Arctic. Studies in plant survival. Ecological case histories of plant adaption to adversity. Stud. Ecol. 11, 47-76.

Dubiel, E. 1991: Ecological observations on vascular plants in the NW Sorkapp Land (Spitsbergen). Prace Bot, 22, 39-45.

Eide, F. 1987: Pollen-morphological studies within northEuropean Ranunculaceae. Ph.D. thesis, Botanical Institute. University of Bergen.

Ekern, K. \& Kildemo, K. 1978: Svalbardreinens ernaring. (The nutrition of Svalbard reindeer.) Hovedfagsoppgave. Norwegian Agricultural College. As

Elvebakk, A. \& Hertel, H. 1996: Part 6. Lichens. In A. Elvebakk \& P. Prestrud (eds.): A catalogue of Svalbard plants, fungi, algae and cyanobacteria. Nor. Polarinst. Skr. 198. 271-359.

Elven, R. \& Elvebakk, A. 1996: Part 1. Vascular plants. In A. Elvebakk \& P. Prestrud (eds.): A catalogue of Svalbard plants, fungi, algae and cyanobacteria. Nor. Polarinst. Skr. $198,9-55$

Fagri, K. \& Iversen, J. 1989: Textbook of pollen analysis. London: John Wiley \& Sons.

Førland, E. J. 1993: Nedbфrsnormaler, normalperiode 19611990. (Precipitation means, 1961-1990.) Oslo: Det Norske Meteorologiske Institutt/Universitetsforlaget.

Frisvoll, A. A. \& Elvebakk, A. 1996: Part 2. Bryophytes. In A. Elvebakk \& P. Prestrud (eds.): A catalogue of Svalbard plants, fiungi. algae and cyanobacteria. Nor. Polarinst. Skr. $198,57-172$

Hisdal, V. 1985. Geography of Svalbard. Polar handbook 6. Oslo: Norwegian Polar Institute.

Hjeljord, O. 1975: Studies of the Svalbard reindeer. Nor: Polarinst. Arb. 1973, 113-123.

Juggins, S. 1993: TRAN version 1.7. (Unpublished computer programme.)

Justesen, J. 1992: Pollenanalyse av fekalier som metode $i$ vegetasjons - og dietunders $\phi k$ kelse. (Pollen analysis of faeces as a method in vegetation and dietary studies.) Hovedfag soppgave, Botanical Institute, University of Bergen.

Kaland. P. E. \& Natvik, Ø. 1993: Core 2.0. (Unpublished computer programme.)

King, F. B. 1977: An evaluation of the pollen contents of coprolites as environmental indicators. J. Arizona Acad. Sci. 12, 47-52.

Krog, J., Wika, M., Lund-Larsen, T., Nordfjell, J. \& Myrnes, I. 1976: Spitsbergen reindeer, Rangifer tarandus platvrhynchus Vrolik: morphology, fat storage and organ weights in the late winter season. Nor. J. Zool. 24, 407-417. 
Krzywinski, K. 1976: En registrering av resent pollenregn malt i forskjellig vegetasjon på Milde, Bergen. (A registration of recent pollen rain in different vegetation types at Milde, Bergen.) Hovedfagsoppgave, Botanical Institute, University of Bergen.

Martin, P. S. \& Sharrock, F. W. 1964: Pollen analysis of prehistoric human feces: a new approach to ethnobotany. Aner. Antic. 30\{2). 168-180.

Moe, D. 1983: Palynology of sheep's faeces relationship between pollen content, diet and local pollen rain. Grana 22, 105-113.

Moe, D. 1996: Coprolite material, a little used source for local environmental studies. A survey with examples from pollenanalytical studies. Pact 50 IV.9, 451-461.

Persen, E., Holand, Ø.. Leifseth, A. B. \& Staaland, H. 1983: Reindeer grazing on Brøggerhalvøya, Svalbard. Acta Zool. Fenn. 175. 35-37.

Prins. H. H. T. 1981: Why are mosses eaten in cold environments only? Oikos 38, 374-380.

Punsvik, T. \& Syvertsen, A. 1978: Vegetasjon og reinbeite $i$ Adventdalen. (Vegetation and reindeer grazing in Adventdalen.) Hovedfagsoppgave. Norwegian Agricultural College. As.

Punsvik, T.. Syvertsen, A. \& Staaland, H. 1980: Reindeer grazing in Adventdalen, Svalbard. In E. Reimers et al. (eds.): Proceedings of the 2nd International Reindeer/Caribou Symposium, Roros, Norway, 1979. Pp. 115-123. Trondheim: Direktorat for Vilt og Ferskvannsfisk (Directorate of Game and Freshwater Fish).

Resvoll, T. R. 1917: Om planter som passer til kort sommer og kold sommer. (Plants adapted to a short and cold summer.) Archin, for Matematikk og Naturvidenskab 35, 6.

Rønning, O. I. 1996: Svalbards flora. Polar handbook 9. Oslo: Norwegian Polar Institute.

Šmilauer, P. 1992: CanoDraw. User's guide. Version 3.0. London: Environmental Change Research Centre, University College.

Srodon. A. 1960: Pollen spectra from Spitsbergen. Folia Quat. $3,1-15$.

Staaland, H. 1984: On the quality of Svalbard reindeer pasture in the summer and autumn. Rangifer 4(1), 16-23.

Staaland. H. 1986: Svalbardreinens ernæring. (The nutrition of the Svalbard reindeer.) In N. A. Øritsland (ed.): Svalbardreinen og dens livgrunnlag. (Svalbard reindeer and their basis for existence.) Pp. 72-91. Oslo: Universitetsforlaget.

Staaland. H., Brattbakk, I., Ekern, K. \& Kildemo, K. 1983: Chemical composition of reindeer forage plants in Svalbard and Norway. Holarct. Ecol. 6. 109-122.

Staaland, H., Jacobsen, E. \& White, R. G. 1979: Comparison of the digestive tract in Svalbard and Norwegian reindeer. Arct. Alp. Res. II(4), 457-466.

Staaland, H. \& Punsvik, T. 1980: Reindeer grazing on Nordaustlandet. Svalbard. In E. Reimers et al. (eds.): Proceedings of the 2nd International Reindeer/Caribou Symposium, Røros, Norway, 1979. Pp. 142-150. Trondheim: Direktorat for Vilt og Ferskvannsfisk (Directorate of Game and Freshwater Fish).

Steffensen, E. L. 1982: The climate of Norwegian Arctic stations. Klima 5, 1-44.

Strasburger, E., Denffer, D., Bell, P. R. \& Coombe. D. 1976. Strasburger's textbook of botany. New Engish edition. London: Longman.

ter Braak. C. J, F. 1987: Ordination. In R. H. G. Jongmann et al. (eds.): Data analysis in community and landscape ecology. Pp. 91-173. Wageningen, The Netherlands: Pudoc.

ter Braak, C. J. F. 1991: CANOCO - a FORTRAN program for canonical community ordination by (principal) (detrended) (canonical) correspondence analysis, principal components analysis and redundance analysis (version 3. 12). Wageningen. The Netherlands: TNO Institute of Applied Computer Science. Statistics Department.

ter Braak, C. J. F. \& Prentice, I. C. 1988: A theory of gradient analysis. Adv. Ecol. Res. 18, 271-317.

Tyler, N. 1993: Svalbardrein. (Svalbard reindeer.) Ottar 2, 51 58.

Tyler, N. J. C. \& Øritsland, N. A. 1989. Why don't Svalbard reindeer migrate? Holarct. Ecol. 12(4), 369-376.

van der Knaap, W. O. 1987: Long-distance transported pollen and spores on Spitsbergen and Jan Mayen. Pollen et Spores 29(4), 449-454.

van der Knaap. W. O. 1989: Past vegetation and reindeer on Edgeøya (Spitsbergen) between c. 7900 and c. 3800 B.P., studied by means of peat layers and reindeer faecal pellets. $y$. Biogeogr. 16, 379-394. 